\title{
Age differences in primary and secondary memory
}

\author{
PAUL W. FOOS, MARK A. SABOL, GUSTAV CORRAL, and LUANA MOBLEY \\ Florida International University, Miami, Florida
}

Fifteen high-frequency words were presented to children (ages 8-12), young adults (ages 20-32), and old adults (ages 60-79) for immediate free recall. Estimations of primary and secondary memory showed that children and old adults had lower primary memory than did young adults and that old adults had lower secondary memory than did children and young adults. Suggestions for dealing with lower primary and secondary memory are made, and future research is suggested.

Human memory is typically divided into at least two major components: primary memory (PM) and secondary memory (SM). PM is considered to be a short-term, limited-capacity space where information processing (e.g., rehearsal and imagery) takes place, whereas SM is a longterm, unlimited storehouse of processed information. Although there is considerable evidence that PM and SM develop over the first 10-15 years of life (e.g., Kail, 1979; Salatas \& Flavell, 1976; Wilson, 1976) and decline with old age (e.g., Craik, 1968; Parkinson, Lindholm, \& Inman, 1982; Wright, 1981), there are few studies that make life-span comparisons. That is, most studies compare young adults to children or to old adults. Children and old adults rarely participate in the same study. Since these earlier studies used different techniques for assessing PM and SM, life-span comparisons across different studies have not been possible. The present study solves this problem by examining PM and SM in preadolescent children, young adults, and old adults in the same study.

\section{METHOD}

\section{Participants}

Twenty people in each of three age groups participated in the experiment. All reported being in good health, and all were native speakers of English. The group of children was composed of 8 females and 12 males between the ages of 8 and 12 (mean $=9.75$ ). The young adult group was composed of 12 females and 8 males between the ages of 20 and 32 (mean $=24.7$ ). The old adult group was composed of 12 females and 8 males between the ages of 60 and 79 (mean $=67.75$ ).

\section{Materials}

Fifteen one- and two-syllable nouns were randomly selected from the highest frequency words (Kucera \& Francis, 1967). Words were recorded at the rate of one word every $2 \mathrm{sec}$ on a Panasonic cassette recorder (Model RQ-2309).

\section{Procedure}

All participants were tested in familiar, comfortable settings: children were tested at their school, young adults were tested at the university, and old adults were tested in a church social hall following ser-

Requests for reprints should be sent to Paul W. Foos, Department of Psychology, Florida International University, Bay Vista Campus, North Miami, FL 33181. vices. To be sure that everyone could hear the recording, part of the instructions were also recorded. Individuals were asked to arrange their seats until all could hear well during the playing (and replaying) of the recorded instructions. Participants were instructed that they would hear a list of words for later recall and that they should try to remember as many words as possible. Following the instructions, the 15-word list was played. Immediately after the last word, all participants were told to write down all the words they could remember.

\section{RESULTS AND DISCUSSION}

Young adults recalled more words (mean $=9.45$ out of 15$)$ than did children (mean $=8.40)$ and old adults $($ mean $=6.75)[F(1,57)=18.19, p<.01]$. Children recalled significantly more than did old adults $[F(1,57)$ $=11.79, p<.01]$. Two different techniques were used to estimate PM and SM for the three age groups. The results of those techniques are shown in Table 1.

The Tulving and Patterson (1968) technique uses the mean number of items recalled from the last four items in the list as an estimate of PM capacity. The estimate of SM is the mean number recalled from the first 11 serial positions. A Newman-Keuls analysis $(p<.05)$ showed that children and old adults had lower PM scores than did young adults and that old adults had lower SM scores than did children and young adults.

The Waugh and Norman (1965) technique, modified by Watkin (1974), estimates PM by using proportion recalled on the last serial position multiplied by seven. SM is the average proportion recalled on serial positions

Table 1

Estimates of PM and SM for Three Age Groups

\begin{tabular}{cccc}
\hline & \multicolumn{3}{c}{ Age Group } \\
\cline { 2 - 4 } Memory & Children & $\begin{array}{c}\text { Young } \\
\text { Adults }\end{array}$ & $\begin{array}{c}\text { Old } \\
\text { Adults }\end{array}$ \\
\hline \multicolumn{4}{c}{ Tulving \& } \\
PM & 2.05 & 2.80 & 1.80 \\
SM & 6.35 & 6.65 & 4.95 \\
Modified Waugh \& Norman (1965) (Watkin, 1974) \\
PM & 5.25 & 7.00 & 3.85 \\
SM & 10.50 & 9.15 & 6.75 \\
\hline
\end{tabular}


4 through 11 multiplied by 15 (i.e., the total number of items in the list). Analyses again showed that children and old adults had lower PM scores than did young adults and that old adults had lower SM scores than did children and young adults.

These results indicate that by late childhood (i.e., age 8-12) SM has developed to the level of young adulthood but that PM has not. For old adults, both PM and SM have declined. In practical terms the results suggest that children and old adults can benefit greatly by learning to write information down. When information is written, the demand on PM is greatly relieved. For old adults, information written down should be retained, perhaps in a notebook, since SM has also declined. Further research should attempt to determine at what age SM (e.g., younger than 8) and PM (e.g., older than 12) reach young adult levels and at what ages they decline in older adults. Work by Schonfield (1965) suggests that SM begins to decline by middle adulthood, whereas work by Foos (1987) suggests that PM does not decline until after 50.

\section{REFERENCES}

CRAIK, F. I. M. (1968). Two components in free recall. Journal of Verbal Learning \& Verbal Behavior, 7, 996-1004.
Foos, P. W. (1987). The decline of working memory in the elderly: Processing vs. capacity. (In preparation)

KAIL, R. (1979). Use of strategies and individual differences in children's memory. Developmental Psychology, 15, 251-255.

KuČERA, H., \& FranCIS, W. N. (1967). Computational analysis of present-day American English. Providence, RI: Brown University Press.

Parkinson, S. R., Lindholm, J. M., \& Inman, V. W. (1982). An analysis of age differences in immediate recall. Journal of Gerontology, 37, 425-431.

Salatas, H., \& Flavell, J. H. (1976). Retrieval of recently learned information: Development of strategies and control skills. Child Development, 47, 941-948.

SchonfiEld, D. (1965). Memory changes with age. Nature, 208, 918.

Tulving, E., \& PATterson, R. D. (1968). Functional units and retrieval processes in free recall. Journal of Experimental Psychology, 77, 239-248.

WATKIN, M. J. (1974). Concept and measurement of primary memory. Psychological Bulletin, 81, 695-711.

Waugh, N. C., \& NoRman, D. (1965). Primary memory. Psychological Review, 72, 89-104.

Wilson, W. P. (1976). Developmental changes in the lag effect: An encoding hypothesis for repeated word recall. Journal of Experimental Child Psychology, 22, 113-122.

WRIGHT, R. E. (1981). Aging, divided attention, and processing capacity. Journal of Gerontology, 36, 605-614.

(Manuscript received for publication December 10, 1986.) 